\title{
Changes in Oxidative Stress and Acid-Base Balance in Men and Women Following Maximal-Intensity Physical Exercise
}

\author{
M. WIECEK ${ }^{1}$, M. MACIEJCZYK ${ }^{1}$, J. SZYMURA ${ }^{2}$, Z. SZYGULA ${ }^{3}$ \\ ${ }^{1}$ Department of Physiology and Biochemistry, Institute of Biomedical Sciences, University School \\ of Physical Education, Krakow, Poland, ${ }^{2}$ Department of Clinical Rehabilitation, University School \\ of Physical Education, Krakow, Poland, ${ }^{3}$ Department of Sports Medicine and Human Nutrition, \\ Institute of Biomedical Sciences, University School of Physical Education, Krakow, Poland
}

Received January 28, 2014

Accepted May 30, 2014

On-line September 5, 2014

\section{Summary}

Oxidative stress may be caused by an increased rate of ATP resynthesis during physical exercise. The aim of this study was to compare changes in the prooxidant-antioxidant state of blood plasma between men and women after maximal-intensity exercise, and to assess the relationship between these changes and the value of the maximal oxygen uptake $\left(\mathrm{VO}_{2 \max }\right)$ as well as between these changes and the value of post-exercise disruptions in acid-base balance. Study participants comprised 10 women (20.7 \pm 0.5 years) and 10 men ( $22.3 \pm 0.5$ years) who were physically active but did not engage in competitive sports training. $\mathrm{VO}_{2 \max }$ was determined via treadmill incremental test $\left(\mathrm{VO}_{2 \max }\right.$ relative to body mass: $44.48 \pm 1.21 \mathrm{ml} / \mathrm{kg} / \mathrm{min}$ and $59.16 \pm 1.55 \mathrm{ml} / \mathrm{kg} / \mathrm{min}$ for women and men, respectively). The level of acid-base balance indicators (ABB), lactate concentration $\left(\mathrm{La}^{-}\right)$, the level of total oxidative status (TOS), the level of total antioxidative capacity (TAC), and uric acid (UA) concentration were measured before and after the test. An oxidative stress indicator (OSI) was also calculated. Men showed a significant post-exercise increase in the level of TOS and OSI, while women showed a significant post-exercise increase in the level of TAC. Post-exercise changes in UA concentration were insignificant. Post-exercise changes in TOC in men depended on the absolute values of $\mathrm{VO}_{2 \max }$, on $\mathrm{VO}_{2 \max } / \mathrm{LBM}$, and on post-exercise changes in La` concentration.

\section{Key words}

Gender differences - Physical capacity • Oxidative stress • Acid-base balance

\section{Corresponding author}

M. Więcek, Department of Physiology and Biochemistry, Institute of Biomedical Sciences, University School of Physical Education, al. Jana Pawla II 78, 31-571 Krakow, Poland. Fax: +481 26831223. E-mail: magdalena.wiecek@awf.krakow.pl

\section{Introduction}

In physiological conditions, a disturbance in the prooxidant-antioxidant balance $(\mathrm{PAB})$ and resulting oxidative stress (OS) can be caused by physical exercise due to excessive production of reactive oxygen species (ROS) in respect to the antioxidant defense capacity. The production mechanism of ROS depends on the duration, intensity, and type of contraction, which in turn are due to a varying engagement of oxidative and substrate-level phosphorylation in the resynthesis of ATP. Increased activity of lactate dehydrogenase, reduced $\mathrm{pH}$, increased catecholamine concentration, and increased muscle temperature are believed to contribute to the production of ROS, such as superoxide anion radical $\left(\mathrm{O}_{2}{ }^{\circ}\right)$, hydroxyl radical $\left({ }^{\circ} \mathrm{OH}\right)$, and hydrogen peroxide $\left(\mathrm{H}_{2} \mathrm{O}_{2}\right)$ (Sies 1997, Powers and Jackson 2008, Fisher-Welman and Bloomer 2009, Powers et al. 2011).

The negative effects of OS are prevented by enzymatic and non-enzymatic antioxidants. Together, these compounds determine the antioxidant capacity (Valko et al. 2007, Powers and Jackson 2008, Durackova 2010). It has been found that high levels of uric acid concentration (UA) are associated with 
increased total plasma antioxidative capacity (TAC) (Kaikkonen et al. 2002, Waring et al. 2003). In addition, estrogen is considered to function as an antioxidant in women (Demirbag et al. 2005).

Results of studies on post-exercise changes in $\mathrm{PAB}$ in men and women are ambiguous. Bloomer and Smith (2009) observed similar changes in men and women in terms of the level of MDA and $\mathrm{H}_{2} \mathrm{O}_{2}$ as well as the activity of xanthine oxidase after an incremental test and a maximal anaerobic power test. Furthermore, no significant differences in lipid peroxidation were found between genders after a marathon run (Kaikkonen et al. 2002). Karabulut (2011) compared results attained by men and women after anaerobic exercise, and found a significant increase in MDA and a decrease in GSH in men, indicating the presence of OS. Some studies conducted on men and women that observed a significant decrease (indicative of OS) of the ratio between the reduced and oxidized form of glutathione (GSH/GSSG) in persons not engaged in competitive sports training who performed an incremental test, do not involve analysis of differences between genders (Subudhi et al. 2003). Numerous studies involved only men (Antonic-Svetina et al. 2010, Berzosa et al. 2011, Leelarungrayub et al. 2011).

Taking into account the inconsistency between the results of the aforementioned research, the varying mechanism of ROS production during aerobic and anaerobic exercise, as well as considerable differences between genders in aerobic capacity (Sparling 1980) and the potential of anaerobic metabolism (Vincent et al. 2004), it is reasonable to conduct an assessment of differences between genders in terms of OS induced by physical exercise accompanied by a maximal oxygen intake $\left(\mathrm{VO}_{2 \max }\right)$ and the concurrent disturbance in acidbase balance.

The aim of our study was to answer the question whether maximal-intensity physical effort induces the same changes in men and women in terms of the level of total oxidative status and total antioxidative capacity of blood plasma, and of uric acid concentration in the serum. The aim of our study was also to verify the hypothesis that the level of oxidative stress depends on maximal oxygen uptake per minute and the degree of disturbances in acid-base balance expressed through a post-exercise increase in lactate concentration in the blood.

\section{Methods}

\section{Participants}

Study participants comprised 20 healthy, college aged (10 men: $22.3 \pm 0.5$ years and 10 women: $20.7 \pm 0.5$ years), non-smoking, physically active volunteers who did not engage in competitive sports training. The women had a regular menstrual cycle (27-32 days) and had not taken any hormonal drugs. The research methodology was approved by the Bioethics Commission of the Regional Medical Chamber and was performed in accordance with the Declaration of Helsinki. The participants were familiarized with the laboratory equipment and research protocol. Prior to taking the exercise tests, the participants underwent a medical qualification procedure to eliminate contraindications to performing maximal-intensity exercise. The exercise tests were conducted under constant medical supervision.

\section{Anthropometric measurements and menstrual cycle analysis}

A day before the exercise tests, the following were measured: body height $(\mathrm{BH})$ using a Martin anthropometer (Poland) with accuracy to $1 \mathrm{~mm}$, body mass (BM) using a Tanita TBF-300 scale (Japan), and skinfold thickness (SF) at three locations on the left side of the body (over the triceps brachii muscle, under the inferior angle of the scapula, and on the abdomen, halfway between the navel and the anterior superior iliac spine). SF was measured using a Harpenden caliper (Poland) with accuracy to $0.1 \mathrm{~mm}$. Body density (Durnin and Womersley 1974), and the percentage of body fat in total body mass was estimated (Siri 1961), and lean body mass (LBM), body fat (BF), and body mass index (BMI) was calculated for each participant. Table 1 shows the participants' somatic characteristics.

Female participants observed a normal course of the menstrual cycle throughout the experiment based on daily measurements of basal body temperature. The choice of the day for testing was validated based on the plasma level of estradiol (follicular phase $0-160 \mathrm{pg} / \mathrm{ml}$, luteal phase $27-246 \mathrm{pg} / \mathrm{ml}$ ) and progesterone (follicular phase $0.32-2.00 \mathrm{ng} / \mathrm{ml}$, luteal phase $1.10-28.00 \mathrm{ng} / \mathrm{ml}$ ).

\section{Exercise protocol}

Study participants performed a laboratory running test with a gradually increasing load (incremental test - IT) on an $\mathrm{h} / \mathrm{p} / \mathrm{Cosmos}$ Saturn treadmill (Germany) inclined at an angle of $0 \%$. The test began with a 4-min 
exercise at the speed of $7.0 \mathrm{~km} / \mathrm{h}$ for men and $6.0 \mathrm{~km} / \mathrm{h}$ for women. Running speed increased every $2 \mathrm{~min}$ by $1.2 \mathrm{~km} / \mathrm{h}$ for men and $1.0 \mathrm{~km} / \mathrm{h}$ for women. The test was conducted until the participant was unable to continue the exercise or until $\mathrm{VO}_{2}$ ceased to increase despite the increasing running speed.

Table 1. Anthropometric characteristics study participants.

\begin{tabular}{lccc}
\hline Variables & Men & Women & P-value \\
\hline Age (years) & $22.3 \pm 0.5$ & $20.7 \pm 0.5$ & 0.03 \\
Body height $(\mathrm{cm})$ & $182.7 \pm 1.6$ & $164.7 \pm 1.0$ & $<0.01$ \\
Body mass $(\mathrm{kg})$ & $80.87 \pm 2.05$ & $55.37 \pm 2.03$ & $<0.01$ \\
Lean body mass $(\mathrm{kg})$ & $67.11 \pm 1.32$ & $43.37 \pm 0.87$ & $<0.01$ \\
Body fat $(\%)$ & $16.85 \pm 1.1$ & $21.2 \pm 1.6$ & 0.04 \\
Body fat $(\mathrm{kg})$ & $13.75 \pm 1.16$ & $11.99 \pm 1.28$ & 0.32 \\
Body mass index $\left(\mathrm{kg} / \mathrm{m}^{2}\right)$ & $24.22 \pm 0.49$ & $20.39 \pm 0.66$ & $<0.01$ \\
\hline
\end{tabular}

Values represent means $\pm \mathrm{SEM}$; differences were accepted as statistically significant at $\mathrm{P}<0.05$ (one-way analysis of variance).

Breathing frequency (BF), tidal volume (TV), pulmonary ventilation (VE), and oxygen uptake $\left(\mathrm{VO}_{2}\right)$ were measured from the second minute before the start of the exercise until the end of the exercise using a Medicro 919 ergospirometer (Finland). The respiratory quotient (RQ) was calculated. Heart rate (HR) was measured from the second minute before the start of the exercise until the end of the exercise using a Polar pulsometer (Finland) at a 5-s recording interval.

The incremental test was conducted before noon in similar ambient conditions (temperature of $20-22^{\circ} \mathrm{C}$ and relative humidity of 50-60\%). On the day of IT and within $24 \mathrm{~h}$ before IT, the participants did not perform any intense physical exercise and did not ingest products that contained caffeine or alcohol, or use any other stimulants. Women were randomly divided into two groups of five persons. One group performed the exercise test during the follicular phase of the menstrual cycle (days 6-9), and the other group performed the test during the luteal phase (days 5-8 after ovulation).

\section{Blood sampling and biochemical analysis}

Acid-base balance

Lactate concentration ( $\left.\mathrm{La}^{-}\right)$and indicators of acid-base balance $(\mathrm{ABB})$, i.e. hydrogen ion concentration $\left(\mathrm{H}^{+}\right)$, bicarbonate ion concentration $\left(\mathrm{HCO}_{3}{ }^{-}\right)$, base excess/deficit (BE), and anion gap $\left(\mathrm{AG}=\left(\mathrm{Na}^{+}+\mathrm{K}^{+}\right)-\left(\mathrm{Cl}^{-}\right.\right.$ $\left.+\mathrm{HCO}_{3}^{-}\right)$) were measured in arterialized blood that was collected from capillaries in the tip of the finger $5 \mathrm{~min}$ before IT and $3 \mathrm{~min}$ after its completion. $\mathrm{ABB}$ were measured using a RapidLab 348 Siemens Analyzer
(Germany) directly after $80 \mu \mathrm{l}$ of blood were collected with lithium heparin as an anticoagulant. To determine the $\mathrm{La}^{-}$concentration, $300 \mu \mathrm{l}$ of blood were drawn into micro test tubes containing K2EDTA and $\mathrm{NaF}$ as a glycolysis inhibitor. The blood was stored in ice for no longer than $20 \mathrm{~min}$ and centrifuged for $3 \mathrm{~min}$ at RCF of $14300 \times \mathrm{g}$ in a MPW 55 centrifuge (Poland). Immediately after centrifugation, $10 \mu \mathrm{l}$ of blood plasma were collected and $\mathrm{La}^{-}$was measured using the colorimetric method with the enzymatic L-Lactate Randox (UK) test. Test sensitivity amounted to $0.165 \mathrm{mmol} / 1$ and linearity amounted up to $19.7 \mathrm{mmol} / \mathrm{l}$. Absorbance was measured at $550 \mathrm{~nm}$ using a UV/Vis Evolution 201 Thermo Scientific spectrophotometer (United States).

\section{Prooxidant-antioxidant balance}

To determine the total oxidative status (TOS), total antioxidative capacity (TAC), and uric acid concentration (UA), venous blood was collected $5 \mathrm{~min}$ before IT, and $10 \mathrm{~min}$ and $24 \mathrm{~h}$ after its completion. To determine TAC and TOS, venous blood samples were drawn into $2 \mathrm{ml}$ vacutainer tubes containing K2EDTA and immediately centrifuged. Plasma samples were drawn into cryotubes and stored for no more than four weeks in $-20{ }^{\circ} \mathrm{C}$ until analysis. TAC and TOS were measured using enzymatic tests developed by Immundiagnostik (Germany). TAC was determined based on the reaction of antioxidants in the sample with a defined amount of $\mathrm{H}_{2} \mathrm{O}_{2}$ provided exogenously. Surplus $\mathrm{H}_{2} \mathrm{O}_{2}$ that remained after elimination by blood plasma antioxidants was assessed. The difference between 
applied and measured $\mathrm{H}_{2} \mathrm{O}_{2}$ concentration in a defined time period was proportional to the reactivity of the antioxidants of the sample (TAC). The total lipid peroxides were measured to determine TOS. In both cases, a reaction in the presence of peroxidase was used. The reaction involved the oxidation of $3,3^{\prime}, 5,5^{\prime}-$ tetramethylbenzidine (TMB) by peroxides present in the sample into a colored product (3,3',5,5'tetramethylbenzidine diimine). Next, $\mathrm{H}_{2} \mathrm{SO}_{4}$ was added to terminate the reaction and the concentration of the product was measured using photometry. Absorbance was measured at $450 \mathrm{~nm}$ using a DRG E-Liza MAT 3000 microplate reader (United States). All assessments were performed twice. No samples with hemolysis or lipemia, which may have distorted the results, were found. Test sensitivity amounted to $130 \mu \mathrm{mol} / 1$ for TAC and $7 \mu \mathrm{mol} / 1$ for TOS. The oxidative stress indicator (OSI) was calculated as the ratio between TOS and TAC. Postexercise percent changes in TOS and TAC in relation to the initial levels were calculated.

To determine UA, venous blood samples were drawn into $2 \mathrm{ml}$ vacutainer tubes containing a coagulation activator. The samples were centrifuged $20 \mathrm{~min}$ after collection. UA was measured directly after $20 \mu \mathrm{l}$ of serum were pipetted, using the colorimetry method with the Uric Acid Randox (UK) test. Test linearity amounted up to $1189 \mu \mathrm{mol} / \mathrm{l}$. Absorbance was measured at $520 \mathrm{~nm}$, using a UV/Vis Evolution 201 Thermo Scientific spectrophotometer (United States).

Venous blood was collected from the antecubital. The samples were centrifuged each time at RCF $1000 \times \mathrm{g}$ for $15 \mathrm{~min}$ in $4{ }^{\circ} \mathrm{C}$ using a MPW 351R refrigerated centrifuge (Poland).

\section{Statistical analysis}

Data were presented as mean values and standard errors (mean $\pm \mathrm{SE}$ ). Data distribution was tested using the Shapiro-Wilk test. The significance of differences between mean values was assessed using oneway or repeated measures two-way ANOVA. If a significant influence of the main factor (SEX, EXERCISE, or SEX and EXERCISE) was found, the significance of differences between particular mean values was assessed using post-hoc analysis (Tukey's range test). Correlations between variables were determined separately for each sex using Pearson's test. Differences were accepted as statistically significant at $\mathrm{P}<0.05$. Statistical calculations were performed using the Statistica 10.0 (Stat-Soft, Inc., USA).

\section{Results}

Men and women differed significantly in terms of maximal oxygen uptake per minute $\left(\mathrm{VO}_{2 \max }\right)$ (Table 2). Absolute values of $\mathrm{VO}_{2 \max }$ were lower by about $48 \%$ in women than in men $(\mathrm{P}<0.01)$. When the results were expressed relative to body mass $\left(\mathrm{VO}_{2 \max } / \mathrm{BM}\right)$ and lean body mass $\left(\mathrm{VO}_{2 \max } / \mathrm{LBM}\right)$, the observed differences between genders decreased to $25 \%$ and $20 \%$, respectively, but were still statistically significant $(\mathrm{P}<0.01)$. Based on the $\mathrm{VO}_{2 \max } / \mathrm{BM}$, the aerobic capacity in women and men can be considered high and very high, respectively (Astrand 1960). No significant differences in $\mathrm{HR}_{\max }$ were found between the compared groups. $\mathrm{VE}_{\max }$ recorded toward the end of IT was lower by about $43 \%$ in women than in men $(\mathrm{P}<0.01)$.

Table 2. Maximal values of cardiorespiratory indicators achieved by men and women during the incremental test.

\begin{tabular}{lccc}
\hline Variables & Men & Women & P-value \\
\hline $\begin{array}{l}\text { Maximal oxygen uptake } \\
\text { (l/min) } \\
\begin{array}{l}\text { Maximal oxygen uptake relative to body mass } \\
\text { (ml/kg/min) }\end{array}\end{array}$ & $4.76 \pm 0.14$ & $2.46 \pm 0.11$ & $<0.01$ \\
$\begin{array}{l}\text { Maximal oxygen uptake relative to lean body mass } \\
\text { (ml/kg/min) }\end{array}$ & $59.16 \pm 1.55$ & $44.48 \pm 1.21$ & $<0.01$ \\
$\begin{array}{l}\text { Maximal heart rate } \\
\text { (b/min) }\end{array}$ & $70.93 \pm 1.47$ & $56.6 \pm 1.83$ & $<0.01$ \\
$\begin{array}{l}\text { Maximal pulmonary ventilation } \\
\text { (l/min) }\end{array}$ & $198 \pm 2.5$ & $197 \pm 2.9$ & 0.72 \\
\hline
\end{tabular}

Values represent means $\pm \mathrm{SEM}$; differences were accepted as statistically significant at $\mathrm{P}<0.05$ (one-way analysis of variance). 
Table 3. The level of indicators of acid-base balance in men and women before and $3 \mathrm{~min}$ after the incremental test.

\begin{tabular}{|c|c|c|c|c|}
\hline Variables & & Before IT & After IT & P-value \\
\hline \multirow{3}{*}{$\begin{array}{l}\text { Hydrogen ion concentration } \\
(\mathrm{nmol} / \mathrm{l})\end{array}$} & Men & $39.77 \pm 0.54$ & $61.88 \pm 2.02$ & $<0.01$ \\
\hline & Women & $40.67 \pm 0.73$ & $57.89 \pm 2.5$ & $<0.01$ \\
\hline & $\mathrm{P}$-value & 0.98 & 0.34 & \\
\hline \multirow{3}{*}{$\begin{array}{l}\text { Base excess/deficit } \\
(\mathrm{mmol} / \mathrm{l})\end{array}$} & Men & $0.62 \pm 0.27$ & $-15.09 \pm 0.64$ & $<0.01$ \\
\hline & Women & $-1.88 \pm 0.82$ & $-13.36 \pm 0.86$ & $<0.01$ \\
\hline & P-value & 0.065 & 0.29 & \\
\hline \multirow{3}{*}{$\begin{array}{l}\text { Bicarbonate ion } \\
\text { concentration }(\mathrm{mmol} / \mathrm{l})\end{array}$} & Men & $25.42 \pm 0.26$ & $13.07 \pm 0.4$ & $<0.01$ \\
\hline & Women & $23.07 \pm 0.81$ & $14.02 \pm 0.59$ & $<0.01$ \\
\hline & P-value & $<0.01$ & 0.62 & \\
\hline \multirow{3}{*}{$\begin{array}{l}\text { Anion gap } \\
(\mathrm{mmol} / \mathrm{l})\end{array}$} & Men & $21.65 \pm 0.62$ & $37.16 \pm 0.77$ & $<0.01$ \\
\hline & Women & $21.5 \pm 0.75$ & $32.16 \pm 1.33$ & $<0.01$ \\
\hline & $\mathrm{P}$-value & 0.99 & $<0.01$ & \\
\hline \multirow{3}{*}{$\begin{array}{l}\text { Lactate concentration } \\
(\mathrm{mmol} / \mathrm{l})\end{array}$} & Men & $2.69 \pm 0.06$ & $15.85 \pm 0.56$ & $<0.01$ \\
\hline & Women & $2.56 \pm 0.23$ & $11.54 \pm 0.98$ & $<0.01$ \\
\hline & $\mathrm{P}$-value & 0.99 & $<0.01$ & \\
\hline
\end{tabular}

Values represent means \pm SEM; differences were accepted as statistically significant at $\mathrm{P}<0.05$ (repeated measures two-way analysis of variance, post-hoc Tukey's range test).

\section{Biochemical indicators}

\section{Acid-base balance}

In the third minute after the incremental test, $\mathrm{La}^{-}$and $\mathrm{AG}$ concentrations were significantly higher in men than in women. Post-exercise $\mathrm{H}^{+}$and $\mathrm{HCO}_{3}^{-}$ concentrations as well as $\mathrm{BE}$ did not differ statistically between the compared groups. In both groups, IT caused significant changes in all analyzed indicators of $\mathrm{ABB}$ and $\mathrm{La}^{-}$concentration (Table 3 ).

\section{Prooxidant-antioxidant balance}

A higher level of TOS and OSI, a lower level of $\mathrm{TAC}$, and a lower UA concentration were observed throughout the test in women compared to men. Table 4 and Figure 1 show the results of the statistical analysis. The incremental test caused an increase in the level of TOS in both groups. Changes in men (an increase of about $43 \%$ ) were significant and significantly higher than in women (an increase of about $6.5 \%$ ). Twenty-four hours after the completion of IT, the level of TOS in men decreased significantly compared to post-exercise values. The level of TAC increased significantly in women following IT. In addition, statistically significant differences between sexes were noted in terms of percent changes in TAC (an increase of about $21 \%$ in women and about $0.6 \%$ in men). The OSI was significantly higher in women than in men before IT and $24 \mathrm{~h}$ after it. IT significantly increased the OSI only in men. Post-exercise changes in UA concentration were insignificant in both groups.

\section{Correlations}

Neither group showed correlation between aerobic capacity expressed through $\mathrm{VO}_{2 \max } / \mathrm{BM}$ and the initial levels of TAC, TOS, and OSI. Only men showed a significant correlation between a post-exercise percent increase in TOS and the following three parameters: the absolute value of $\mathrm{VO}_{2 \max }(\mathrm{r}=0.80), \mathrm{VO}_{2 \max } / \mathrm{LBM}(\mathrm{r}=0.72)$, and a post-exercise increase in $\mathrm{La}^{-}$concentration $(\mathrm{r}=0.65)$.

\section{Discussion}

The aim of the research was to compare changes in the prooxidant-antioxidant balance (PAB) of blood plasma in men and women following maximal-intensity exercise, and to assess the relationship between these changes and the value of $\mathrm{VO}_{2 \max }$ as well as between these changes and the level of post-exercise disturbances in the acid-base balance. 
Table 4. The level of indicators of prooxidant-antioxidant balance in men and women before and after the incremental test (IT).

\begin{tabular}{|c|c|c|c|c|c|c|}
\hline \multirow{2}{*}{ Variables } & & \multirow{2}{*}{$\begin{array}{c}\text { Before IT } \\
1\end{array}$} & \multirow{2}{*}{$\begin{array}{c}10 \text { min after IT } \\
2\end{array}$} & \multirow{2}{*}{$\begin{array}{c}24 \text { h after IT } \\
3\end{array}$} & \multicolumn{2}{|c|}{ P-value } \\
\hline & & & & & $2-1$ & $2-3$ \\
\hline \multirow{3}{*}{$\begin{array}{l}\text { Total oxidative status } \\
(\mu \mathrm{mol} / \mathrm{l})\end{array}$} & Men & $264.59 \pm 44.86$ & $361.63 \pm 52.02$ & $256.14 \pm 45.48$ & $<0.01$ & $<0.01$ \\
\hline & Women & $447.09 \pm 39.90$ & $462.46 \pm 29.54$ & $414.75 \pm 37.80$ & 0.98 & 0.29 \\
\hline & P-value & 0.056 & 0.55 & 0.13 & & \\
\hline \multirow{3}{*}{$\begin{array}{l}\text { Total antioxidative capacity } \\
(\mu \mathrm{mol} / \mathrm{l})\end{array}$} & Men & $356.00 \pm 6.31$ & $357.89 \pm 9.87$ & $333.96 \pm 19.38$ & 0.99 & 0.69 \\
\hline & Women & $225.11 \pm 30.22$ & $274.27 \pm 42.95$ & $236.65 \pm 31.70$ & 0.047 & 0.23 \\
\hline & P-value & $<0.01$ & 0.14 & 0.061 & & \\
\hline \multirow{3}{*}{$\begin{array}{l}\text { Uric acid concentration } \\
(\mu \mathrm{mol} / \mathrm{l})\end{array}$} & Men & $423.75 \pm 34.37$ & $447.14 \pm 24.24$ & $399.66 \pm 29.98$ & 0.82 & 0.17 \\
\hline & Women & $266.12 \pm 19.99$ & $294.19 \pm 21.16$ & $278.86 \pm 15.53$ & 0.70 & 0.97 \\
\hline & P-value & $<0.01$ & $<0.01$ & 0.02 & & \\
\hline
\end{tabular}

Values represent means \pm SEM; differences were accepted as statistically significant at $P<0.05$ (repeated measures two-way analysis of variance, post-hoc Tukey's range test, and statistical power of tests (1- $\beta$ ) for comparisons between genders at $P=0.05: 0.69$ for TOS, 0.91 for TAC, and 0.99 for UA).

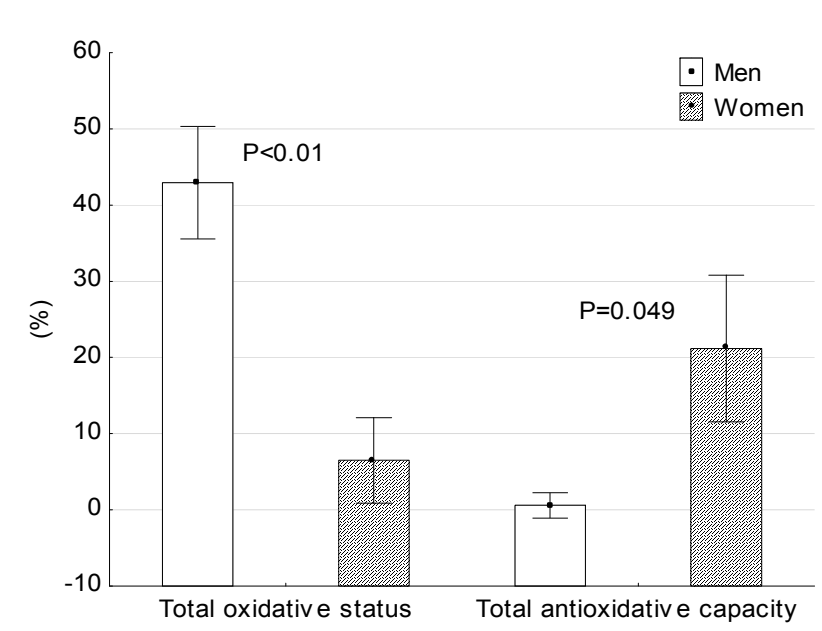

A

Fig. 1. Percent changes in total oxidative status (TOS) and total antioxidative capacity (TAC) of blood plasma (A) following the incremental test (IT) in women and men and values of the oxidative stress indicator (B) in women and men prior to and after the incremental test (IT). Values represent means \pm SEM; differences were accepted as statistically significant at $P<0.05,(\mathbf{A})$ one way analysis of variance, statistical power $(1-\beta)$ for comparisons between sexes at $P=0.05: 0.96$ for \%TOS and 0.51 for \%TAC; (B) repeated measures two-way analysis of variance, post-hoc Tukey's range test, and statistical power (1- $\beta$ ) for comparisons between sexes at $\mathrm{P}=0.05$ : 0.98 for the OSI.

This study found differences in the level of PAB in the blood of men and women prior to the performed exercise. The levels of TOS and OSI were higher, and the levels of TAC and UA concentration were lower in women than in men. Kaikkonen et al. (2002) observed a lower level of TAC and a higher level of TOS in women than in men, similarly to the results obtained in this study. In addition, Dopsaj et al. (2011), in a study with 138 young persons (including 73 women) who did

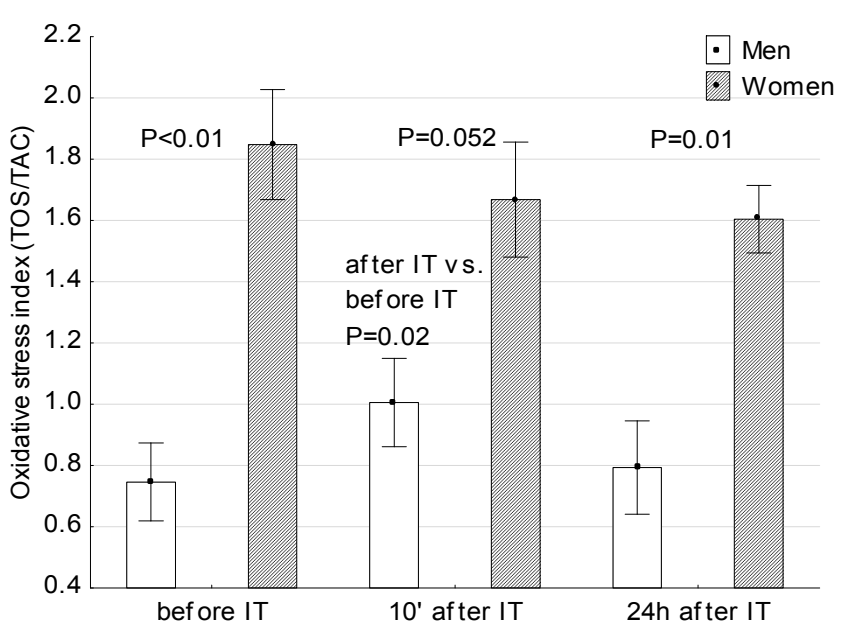

B not engage in competitive sports training found that women showed a shift in PAB toward oxidation, as indicated by a significantly higher level of oxidized forms of lipids and $\mathrm{H}_{2} \mathrm{O}_{2}$ compared to men. However, the above results contradict previous research that found no significant differences between genders in the level of MDA and the activity of antioxidant enzymes (SOD and GPx) in children, adults, and older persons (Ozbay and Dulger 2002), or that found a significantly lower level of 
8-iso-prostaglandin (8-iso-PGF2 $\alpha$ ) in women than in men (Sakano et al. 2009).

An unambiguous assessment of PAB is difficult due to the versatile effect of ROS and numerous mechanisms of enzymatic antioxidant defense (SOD, CAT, and GPx) and non-enzymatic antioxidant defense (glutathione, vitamin A, vitamin E, vitamin C, uric acid, and albumins). Studies assess various indicators of oxidation and various antioxidants (Powers and Jackson 2008). This study determined antioxidant capacity based on the amount of $\mathrm{H}_{2} \mathrm{O}_{2}$ bound by antioxidants present in the blood plasma. Such an assay allows the full antioxidant defense capacity of a sample to be assessed and can be used to assess PAB in many disorders as well as to monitor exercise-related oxidative stress (Kusano and Ferrari 2008, Marin et al. 2013). This study also involved an assessment based on the OSI. The level of OSI for blood plasma may indicate the magnitude of changes that occur in cells (Rabus et al. 2008).

It is well established that regular physical activity increases physical capacity as expressed by the value of $\mathrm{VO}_{2 \max } / \mathrm{BM}$ and increases the activity of mitochondrial SOD in myocytes, which in turn improves antioxidant capacity, thus allowing for a more efficient neutralization of ROS and decreased production of lipid peroxides (Majerczak et al. 2010). Men who participated in this study showed a higher aerobic capacity than women. However, no correlation was found in either group between $\mathrm{VO}_{2 \max } / \mathrm{BM}$ and any of the following parameters: the initial level of TAC, the level of TOS, and the OSI.

To induce exercise-related changes in the indicators of OS, this study used a running test with an incrementally increasing load that lasted until individual maximal load was reached. Such exercise leads to maximal engagement of oxidative phosphorylation with simultaneous involvement of anaerobic processes of ATP production. It also leads to considerable disturbances in acid-base balance: when the lactate threshold is exceeded, a major increase in epinephrine and norepinephrine concentrations in the blood occurs (Langford et al. 2001, Mikulski et al. 2008). Furthermore, following the maximal exercise, an increase in the level of IL-1 and TNF- $\alpha$ occurs, which indicates that inflammatory processes were activated (Damirchi et al. 2011, Leelarungrayub et al. 2011). Therefore, the test is a type of exercise that engages multiple mechanisms of ROS production. Both aerobic and anaerobic exercise is known to lead to disturbances in PAB by shifting it toward oxidation (Bloomer and Smith 2009, Karabulut 2011). At the same time, the exercise test allowed us to directly determine $\mathrm{VO}_{2 \max }$, which is a general indicator of a number of functions of oxygen supply and thus designates human aerobic capacity (Astrand 1960, Bassett and Howley 2000).

Our study suggests that significant differences occur between men and women in terms of indicators of OS during exercise. The incremental test showed a postexercise increase of about $21 \%$ in TAC of the blood plasma of women and caused only a slight increase (of about $6.5 \%$ ) in the level of TOS in women. On the other hand, men displayed a significant increment in the level of TOS without clear post-exercise changes in the level of TAC and UA concentration. The aforementioned changes caused a significant post-exercise increase in OSI only in men. Changes in TOS among men depended on absolute values of $\mathrm{VO}_{2 \max }$ and on values of $\mathrm{VO}_{2 \max }$ relative to LBM. Because physical exercise causes the level of estradiol in the blood to increase (Copeland et al. 2002), the observed differences may have been a result of an indirect effect of the higher level of estradiol in women on the expression of genes that encode antioxidant enzymatic proteins (Vina et al. 2011). Confirmation of this could be a significant increase in the activity of SOD following an incremental test only in women (Akkus 2011). Rush and Sandiford (2002) observed a significantly higher post-exercise activity of GPx in women than in men, although the correlation between the level of estradiol and the activity of GPx was not confirmed. In this study, no correlation was found between post-exercise changes in the level of TAC and the value of $\mathrm{VO}_{2 \max }$ or between post-exercise changes in the level of TAC and $\mathrm{La}^{-}$concentration in women.

We may assume that differences between genders in terms of post-exercise changes in the level of TOS are affected by the considerable difference in anaerobic potential between men and women (Vincent et al. 2004), as confirmed by greater post-exercise disturbances of the acid-base balance and a higher increase in lactate concentration in the blood of men than women, observed in this study. Furthermore, a correlation was also observed between post-exercise changes in $\mathrm{La}^{-}$ concentration and changes in the level of TOS in men. No such correlation was observed in women.

Men show a greater activity of enzymes related to anaerobic metabolism: phosphofructokinase, lactate dehydrogenase, and glycogen phosphorylase (Green et al. 1984, Simoneau and Bouchard 1989, Esbjornsson et al. 
1993). Moreover, studies observed that men showed a significantly higher level of catecholamines following anaerobic exercise (Gratas-Delmarche et al. 1994, Weber and Schneider 2000). This observation indicates that men use glycogen more efficiently as a metabolic substrate during anaerobic glycolysis with the production of lactate, hydrogen ions, and ATP (Esbjörnsson-Liljedahl et al. 1999, Weber and Schneider 2000). A metabolite of ATP is a substrate for xanthine oxidase and may cause excessive oxidative stress.

In sum, the obtained results allow for the conclusion that changes in the prooxidant-antioxidant balance of the blood caused by maximal-intensity physical exercise differ between men and women. Men show a considerable shift in PAB toward oxidation with no clear increase in the antioxidant capacity of the blood plasma. Women show only slight post-exercise changes in the level of TOS of the blood plasma due to an increase in antioxidant capacity. Post-exercise changes in the level of TOS in men depend on the value of $\mathrm{VO}_{2 \max }$ and on post-exercise changes in $\mathrm{La}^{-}$concentration. The lack of such correlations in women may indicate that other factors, not assessed in this study, affected postexercise oxidative stress in this group (e.g. post-exercise changes in estradiol concentration or changes in interleukin concentration).

\section{Conflict of Interest}

There is no conflict of interest.

\section{Acknowledgements}

This study has been realized under Project N N404 071240, financed by the National Science Center (Poland), and as part of statutory research (267/IFC/2010) of the University School of Physical Education in Krakow (Poland). Assistance provided during the research by Szczepan Wiecha is greatly appreciated.

\section{References}

AKKUS H: Effects of acute exercise and aerobic exercise training on oxidative stress in young men and women. Afr $J$ Pharm Pharmacol 5: 1925-1931, 2011.

ANTONCIC-SVETINA M, SENTIJA D, CIPAK A, MILICIC D, MEINITZER A, TATZBER F, ANDRISIC L, ZELZER S, ZARKOVIC N: Ergometry induces systemic oxidative stress in healthy human subjects. Tohoku J Exp Med 221: 43-48, 2010.

ASTRAND I: Aerobic work capacity in men and women with special reference to age. Acta Physiol Scand 49: 1-92, 1960.

BASSETT DR, HOWLEY ET: Limiting factors for maximum oxygen uptake and determinants of endurance performance. Med Sci Sports Exerc 32: 70-84, 2000.

BERZOSA C, CEBRIAN I, FUENTES-BROTO L, GOMEZ-TRULLEN E, PIEDRAFITA E, MARTINEZBALLARIN E, LOPEZ-PINGARRON L, REITER RJ, GARCIA JJ: Acute exercise increases plasma total antioxidant status and antioxidant enzyme activities in untrained men. J Biomed Biotechnol 2011: 540458, 2011.

BLOOMER RJ, SMITH WA: Oxidative stress in response to aerobic and anaerobic power testing: influence of exercise training and carnitine supplementation. Res Sports Med 17: 1-16, 2009.

COPELAND JL, CONSITT LA, TREMBLAY MS: Hormonal responses to endurance and resistance exercise in females aged 19-69 years. J Gerontol A Biol Sci Med Sci 57: B158-B165, 2002.

DAMIRCHI A, RAHMANI-NIA F, MEHRABANI J: Effect of a single bout graded exercise on the cytokines response and insulin resistance index. Brazilian Journal of Biomotricity 5: 132-140, 2011.

DEMIRBAG R, YILMAZ R, EREL O: The association of total antioxidant capacity with sex hormones. Scand Cardiovasc J 39: 172-176, 2005.

DOPSAJ V, MARTINOVIC J, DOPSAJ M, STEVULJEVIC JK, BOGAVAC-STANOJEVIC N: Gender-specific oxidative stress parameters. Int J Sports Med 32: 14-19, 2011.

DURACKOVA Z: Some current insights into oxidative stress. Physiol Res 59: 459-469, 2010.

DURNIN JV, WOMERSLEY J: Body fat assessed from total body density and its estimation from skinfold thickness: measurements on 481 men and women aged from 16 to 72 years. Br J Nutr 32: 77-97, 1974. 
ESBJORNSSON M, SYLVEN C, HOLM I, JANSSON E: Fast twitch fibres may predict anaerobic performance in both females and males. Int $J$ Sports Med 14: 257-263, 1993.

ESBJORNSSON-LILJEDAHL M, SUNDBERG CJ, NORMAN B, JANSSON E: Metabolic response in type I and type II muscle fibers during a 30-s cycle sprint in men and women. J Appl Physiol 87: 1326-1332, 1999.

FISHER-WELLMAN K, BLOOMER RJ: Acute exercise and oxidative stress: a 30 year history. Dyn Med 8: 1, 2009.

GRATAS-DELAMARCHE A, LE CAM R, DELAMARCHE P, MONNIER M, KOUBI H: Lactate and catecholamine responses in male and female sprinters during a Wingate test. Eur J Appl Physiol Occup Physiol 68: 362-366, 1994.

GREEN HJ, FRASER IG, RANNEY DA: Male and female differences in enzyme activities of energy metabolism in vastus lateralis muscle. J Neurol Sci 65: 323-331, 1984.

KAIKKONEN J, PORKKALA-SARATAHO E, TUOMAINEN TP, NYYSSONEN K, KOSONEN L, RISTONMAA U, LAKKA HM, SALONEN R, KORPELA H, SALONEN JT: Exhaustive exercise increases plasma/serum total oxidation resistance in moderately trained men and women, whereas their VLDL + LDL lipoprotein fraction is more susceptible to oxidation. Scand J Clin Lab Invest 62: 599-607, 2002.

KARABULUT AB: Effect of exhaustive exercise on oxidative stress and adenosine deaminase activities in women compared to men. J US-China Med Sci 8: 150-155, 2011.

KUSANO C, FERRARI B: Total antioxidant capacity: a biomarker in biomedical and nutritional studies. $J$ Cell $\mathrm{Mol}$ Biol 7: 1-15, 2008.

LANGFORD J, ZARZECZNY R, NAZAR K, KACIUBA-USCILKO H: The effect of low-carbohydrate diet on the pattern of hormonal changes during incremental, graded exercise in young men. Int J Sport Nutr Exerc Metabol 11: 248-257, 2001.

LEELARUNGRAYUB D, KHANSUWAN R, POTHONGSUNUN P, KLAPHAJONE J: N-acetylcysteine supplementation controls total antioxidant capacity, creatine kinase, lactate, and tumor necrotic factor-alpha against oxidative stress induced by graded exercise in sedentary men. Oxid Med Cell Longev 2011: 329643, 2011.

MAJERCZAK J, RYCHLIK B, GRZELAK A, GRZMIL P, KARASINSKI J, PIERZCHALSKI P, PULASKI L, BARTOSZ G, ZOLADZ JA: Effect of 5-week moderate intensity endurance training on the oxidative stress, muscle specific uncoupling protein (UCP3) and superoxide dismutase (SOD2) contents in vastus lateralis of young, healthy men. J Physiol Pharmacol 61: 743-751, 2010.

MARIN DP, BOLIN AP, CAMPOIO TR, GUERRA BA, OTTON R: Oxidative stress and antioxidant status response of handball athletes: implications for sport training monitoring. Int Immunopharmacol 17: 462-470, 2013.

MIKULSKI T, ZIEMBA A, NAZAR K: Influence of body carbohydrate store modification on catecholamine and lactate responses to graded exercise in sedentary and physically active subjects. $J$ Physiol Pharmacol 59: 603-616, 2008.

OZBAY B, DULGER H: Lipid peroxidation and antioxidant enzymes in Turkish population: relation to age, gender, exercise, and smoking. Tohoku J Exp Med 197: 119-124, 2002.

POWERS SK, JACKSON MJ: Exercise-induced oxidative stress: cellular mechanisms and impact on muscle force production. Physiol Rev 88: 1243-1276, 2008.

POWERS SK, TALBERT EE, ADHIHETTY PJ: Reactive oxygen and nitrogen species as intracellular signals in skeletal muscle. J Physiol 9: 2129-2138, 2011.

RABUS M, DEMIRBAG R, SEZEN Y, KONUKOGLU O, YILDIZ A, EREL O, ZEYBEK R, YAKUT C: Plasma and tissue oxidative stress index in patients with rheumatic and degenerative heart valve disease. Arch Turk Soc Cardiol 36: 536-540, 2008.

RUSH JW, SANDIFORD SD: Plasma glutathione peroxidase in healthy young adults: influence of gender and physical activity. Clin Biochem 36: 345-351, 2003.

SAKANO N, WANG DH, TAKAHASHI N, WANG B, SAURIASARI R, KANBARA S, SATO Y, TAKIGAWA T, TAKAKI J, OGINO K: Oxidative stress biomarkers and lifestyles in Japanese healthy people. J Clin Biochem Nutr 44: 185-195, 2009.

SIES H: Oxidative stress: oxidants and antioxidants. Exp Physiol 82: 291-295, 1997. 
SIMONEAU JA, BOUCHARD C: Human variation in skeletal muscle fiber-type proportion and enzyme activities. $\mathrm{Am}$ J Physiol 257: E567-E572, 1989.

SIRI WE: Body composition from fluid spaces and density: analysis of methods. 1961. Nutrition 9: 480-491, 1993.

SPARLING PB: A meta-analysis of studies comparing maximal oxygen uptake in men and women. Res $Q$ Exerc Sport 51: 542-552, 1980.

SUBUDHI AW, FU MX, STROTHKAMP KG, MURRAY DM: Effect of graded exercise on blood glutathione status in trained and untrained humans. Int Sports J 7: 82-90, 2003.

VALKO M, LEIBFRITZ D, MONCOL J, CRONIN MT, MAZUR M, TELSER J: Free radicals and antioxidants in normal physiological functions and human disease. Int J Biochem Cell Biol 39: 44-84, 2007.

VINA J, GAMBINI J, LOPEZ-GRUESO R, ABDELAZIZ KM, JOVE M, BORRAS C: Females live longer than males: role of oxidative stress. Curr Pharm Des 17: 3959-3965, 2011.

VINCENT S, BERTHON P, ZOUHAL H, MOUSSA E, CATHELINE M, BENTUE-FERRER D, GRATASDELAMARCHE A: Plasma glucose, insulin and catecholamine responses to a Wingate test in physically active women and men. Eur J Appl Physiol 91: 15-21, 2004.

WARING WS, CONVERY A, MISHRA V, SHENKIN A, WEBB DJ, MAXWELL SR: Uric acid reduces exerciseinduced oxidative stress in healthy adults. Clin Sci 105: 425-430, 2003.

WEBER CL, SCHNEIDER DA: Maximal accumulated oxygen deficit expressed relative to the active muscle mass for cycling in untrained male and female subjects. Eur J Appl Physiol 82: 255-261, 2000. 